\title{
The Romanian Goddess Ileana Simziana the Sun's sister
}

\section{Ana R. Chelariu}

The large number of statuettes from late Neolithic found in the aria called the Old Europe, including the present day Romanian territory and its surroundings, are archaeological evidences of civilizations awaiting for an in depth investigation. The main character of all these archaeological findings is the Great Goddess, the source of life, feeder of men and animals. She is figured as a snake, bird or fish goddess, covering all aspects of life as protectress of all creatures living in the air, the waters or underground. She is the dominant character of the pre-historic mythology, mistress of the entire nature, creator and protector of animal and vegetal life, goddess of fertility and rejuvenation, of the mystery of birth and death, holding powers over life and death. The mother of all gods, she has power over them, as she can generate life without a male, as the only ruler over the earth and sky. This powerful mythical figure survived in the Indo-European pantheon, with characteristics surfacing in almost all the feminine divinities of the classical mythologies.

In the Romanian folklore one can recognize this pre-historic goddess in the character of Ileana Simziana, Iana Sânziana or Ileana Cosânzeana, the most adorned fairy of the land. She is the heroine of numerous songs, carols, and fairy tales; she is the most beautiful of all fairies, their queen, so beautiful that 'one could look at the sun but not at her'.

This Romanian fairy queen is best represented in one of the most popular song, The Sun and the Moon, interpreted by special bards at community fests, telling the story of the sun who wants to get married; because he could not find anywhere a girl as beautiful as his own sister, Ileana, he asks her hand in marriage. To avoid such sin she starts asking him impossible tasks, such as to build first a copper bridge over the sky, then a silver one, and then a gold one, all easily fulfilled by the astral divinity. At last, to escape the unwanted wedding she throws herself into the sea, turning into a fish. God takes petty on her and raises her into the sky, as the moon. (Alexandri 1866)

The mythical motif of the wedding or erotic relationship between the sun and the moon is to be found in many IndoEuropean traditions, although, the many different characteristics attributed to these divinities generate sometimes confusions between the divine pair sun-moon and divinities associated with the sun and the moon that are also brother and sister. The motif of their marriage is found in a fable by Phaedrus, where the frogs are worried that the sun wants to marry and have children, which could mean more suns and heat; they start a big noise that rises to Jupiter's ears. (Phaedrus Ranae ad solem I6) This version is popular south of the Danube, together with the one in which the sun falls in love with a mortal girl, more common to Serbia, Bulgaria, and could be found also in the Romanian song "Chicory". (Vrabie 1966)

To establish the goddess position on the gods' pantheon in association with the luminous divinity of the sun, we could examine the many examples of brother and sister that are also the sun and the moon from classic mythology, among whom the most important is the divine pairs ZeusHera. Brother/husband and sister/wife they are often associated with the moon and the bull, as in the description: Hera, with her 
cow eyes, and Zeus, her bull consort. The divine pair Artemis-Apollo although associated with the sun and the moon does not seem to be involved in an erotic relationship. But Selene, the moon goddess, appears sometimes as Helios' sister, and sometimes as his wife. In her myth, every night Selene goes down to Mount Latmos in Karia, where in the darkness of the cave she kisses Endymion, her sleepy lover. Although in some stories Endymion is a mortal, his name is one of the many callings of the sun. According to Max Müller, in some Greek dialect enduo was used in the sense of the sun sinking by night in his mother's purifying water, and from this was formed endumion to express the sunset. In time, people would say "Selene loves and watches Endymion", meaning 'it is getting late', or, "Selene embraces Endymion" for 'the sun is setting and the moon is rising', and the original meaning of his name would be forgotten. (Müller 1872: 52-141)

The motif of a girl refusing to marry and throwing herself into the sea is also found in a Minoan legend about the goddess Britomartis, a nymph in service of Artemis, who runs away from the attentions of Minos, and jumps over a cliff into the sea; she is caught and saved by some fishermen, and brought to the island of Aigina, where she becomes a deity. (Callimachus Hymn to Artemis)

In the Vedic hymns, Yama, the god of death and the sun god in the same time, together with his sister Yami, are the divine twins creators of humanity. The goddess Yami, as the Romanian one, refuses to marry her brother, arguing the immorality of such an act, but her Persian counterpart will submit to it (Puhvel 1987).

In the Baltic dainas the moon is a male deity and the sun a female and their marriage results in many children, the stars. (Dundzila 1991) In the Nordic sagas the sun is also female, as in the Baltic songs, and her companion, the moon is a male; they are children of Mundilfari, thus brother and sister. (Snorri The Prose of Edda 2005: 19) In Scandinavian mythology we find that Njördhr, the oldest among Vanir, married his sister and had as children the divine pair: Freyr, associated with the sun, the sky and the rain, and his sister Freyja, the most beautiful and fair among the goddesses. (Puhvel 1987: 208)

Ileana Sânziana / Cosânzeana / Simziana, the queen fairy in the Romanian folklore, the sun's sister, is a brilliant goddess with golden hair associated with the waving fields of wheat. Her epithets are 'the beautiful', the moon fairy, 'lady of the flowers', protectress of the wild animals and the forests. In some Romanian Christmas carols she appears carried in a silk hammock hooked sometimes between a stag's horns, sometimes between a bull's horns. This archaic divinity, as the goddess from Chatai-Huyul holding the lunar horn, the new moon, indicating the cyclical death and resurrection, has the function of Terra Mater, a divinity considered to pre-date the arrival of the Indo-Europeans. Her paradoxical character is illustrated by her duplicity,virginity-maternity,

contradictions that indicate the archaic mystery of the divine persisting in many European myth and legends. Perhaps the splendor of this archaic divinity is illustrated best in the Greek character of Hera bo-opis 'cow-eyed', the Queen of Evening Sky, of full moon, together with Demeter, the distressed mother, whereas the virgins Artemis, Persephone and Helen are goddesses of the new moon, the growing moon.

The name of the Romanian deity, Ileana, sends us to the Greek goddess Helen, both related to an archaic goddess mentioned in Mallory-Adams's Encyclopedia: *il(i)eh ${ }_{a}$ 'goddess name', Lat. Ilia 'Numitor's daughter', Skt. Ilā-Idā 'Manu's daughter'. Note that Ilia was the daughter of the progenitor of Romulus and Remus, the Divine Twins, and the OInd Ila was the granddaughter of Vivasvat, father of the twins Yama and Yami, as Helen was the 
twin sister of the Dioscuroi. (MalloryAdams 1997:232) Other researchers consider Helen a pre-Doric version of the 'tree-goddess' having roots in the substratum, "...her name does suggest the Vedic Sūryā (Helénē perhaps from Swelenā, cognate with Helios $<*$ Sāweliyos 'Sun' and with Avestan xvarэnah <*swelnos 'solarity')" Puhvel (1987: 143). It seems therefore, possible that this archaic deity, this goddess Ilia, the Helen of Greek tradition, and the Romanian Ileana, the sun's sister, are all related.

Helen is portrayed on monuments between her two brothers, Kastor and Polydeukes, holding the lunar horn, the growing moon, while the brothers have stars on their hats and tunics. The relationship between the lunar horn and Helen is also reflected in an old Greek tongue twist: $\varepsilon \lambda \varepsilon v \eta \sigma \varepsilon \lambda \eta v \eta$, meaning that the egg holding Helen fell from the moon (Chapouthier 1935). She was believed to be the most beautiful woman in the world, as the Romanian Ileana, and displays similar connection to flowers as it is found in a tradition in Sparta where young girls would hang flower wreathes from a certain tree consecrated to her. This may be based on the story in which she was hanged by the orders of a jealous queen, thus her other name Helen Dendritis (Chapouthier 1935). Likewise, there was the Romanian custom held in late spring on the day of Sânziene, flower fairies and forest spirits, Ileana's companions, when Romanian girls would make flower wreathes and throw them on the house chimney, hoping to get married that year. (Ghinoiu 2003)

Ileana's other appellative, Simzianal Sânziana/Cosenzeana/Cosân-zeana was the subject of various controversial explanations. In the Explicative Romanian Dictionary (Dictionarul explicativ al limbii romane, DEX online) the etymology offered for this appellative is the Latin group sanctus dies Johannis (an opinion shared by many prominent Romanian linguists), based on the fact that Sânziene day is celebrated on June $24^{\text {th }}$ Saint John Day. This day was established as the Nativity of St John the Baptist, as listed by the Council of Agde, France, in 506 AD, a the Christian church attempt to associate a feast to the summer solstice folk ceremonies celebrated all over Europe, even though there was no religious connection between the two. The Romanian Simziene/Sânziene, are fairies feared by all, associated with the nocturne rites to collect powerful medicinal plants, and have little if any relation to the Christian Saint who baptized Jesus. It is supposed that the phonological innovation sanctus dies Johannis $>\operatorname{sim}(\mathrm{pt})-\mathrm{dzi}-$ iuane>sânziane (Candrea 1927) incorporated this major Christian Saint in popular customs associating His birth day with the goddess of the land Ileana, while remaining in common and religious usage with His original name as Sântioan $<$ Sanctus Ioannis $<$ Greek Iwávvns, also known in the northern part of the country as Sâmt ion, Sâmčiuonu, Suntiuonu (Bolocan 2012). Yet, it is difficult to accept that the appellative denominating Saint John's fest became a qualifier for the most beloved fairy of the land Ileana Simziana/Sânziana and her entourage of fairies.

Mircea Eliade used the concept of Diana Sancta, Sancta Diana $>$ Sanziana, assuming that the Rom. -ziana is a development from the Roman goddess Diāna. Based on the adjective dius $<*$ diwios the form Diana $<$ Diviānā, is a feminine of the sky god Dius, as in Dea Dia, related to Jupiter and meaning just 'divine' (Puhvel 1987: 151). The relation between this Latin deity and the Romanian Ileana, zâna florilor, sora soarelui, 'the flowers fairy, the sun's sister,' may be difficult to establish, since Diana is not known to have the luminous aster as her brother. Perhaps a better approach to understand this archaic divinity would be to consider her appellatives Simziana in 
connection with her attributes of the Queen of the flowers and the forests, the Earth Goddess, found in the Thracian mythology as $\Sigma \varepsilon \mu \varepsilon \lambda \eta$ 'Mother of Earth', and Semele, $\delta \iota \omega \sigma \xi \varepsilon \mu \varepsilon \lambda \omega$, mother of Dyonisos, subject of a cult among the Phrigians as well as the Scythes. This Semele, believed to be Cadmus' daughter, whose name means 'earth' has correspondences in IndoEuropean languages: in Thracian and

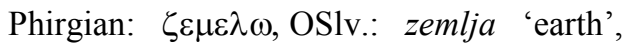
Lithuanian Zemyna 'Earth Goddess,' cognate with Lat. Humus, Gr. $\Xi \alpha \mu-\alpha l, \Xi \alpha \mu-v v \eta$, Demeter's name, and possibly with the Cretan $\delta \eta \alpha i$, Ionic $\zeta \eta \alpha i$ meaning "barley", so that she is the CornMother and the giver of food. The Lithuanian goddess Zemyna, Zemyne, Zemynele, and the Latvian Zemes, "the Baltic Earth Goddess is both grain and mother-nourisher, out of whom humans arise and to whom they return" (Dundzila 1991). The Proto-Indo-European root for 'earth' as listed by Mallory-Adams (2006) is *dhéĝhōm-, Skt kşam, Av za, zam, zme, Grk khthōn, Lat humus, Lith žēme, OCS zemlja, Alb dhe, Hit tēkan, Toch A tkam; it survived as 'human being, earthly' and as I mentioned above as 'goddess' in Phirgian $\xi \varepsilon \mu \varepsilon \lambda \omega$, Thracian $\Sigma \varepsilon \mu \varepsilon \lambda \eta$ 'Mother of Earth'. We can recognize how for thousands of years the essential characteristics of the Earth Goddess remained the same, as in Demeter, Semele, Zemyne, and even at a later date as a male deity, the Dacian Zamolxes, the god who disappeared underground for a number of years. Among the few known Dacian words, preserved by Dioscorides, there is $\delta l \varepsilon \sigma \varepsilon \mu \alpha$ 'lumînărică', a small plant which makes a bright yellow flower, formed of the I.E. root $* d e i-$-, di-, dia-, 'bright, sun ray' and $\sigma \varepsilon \mu \alpha$ 'Earth', thus 'light coming from the ground', attesting the presence of the word on the Dacian territory. This the PIE *dhéghōm- 'earth' may help explain the appellative Ileana Sim-ziana, meaning the fairy of the Earth, of flowers, of the forests, and her companions the simziene/sinziene, the Romanian word for fairies of the land. Parallel with the form Simziana, that of Sânziana, may be a result of the Latin influence, a contamination with sanctus, $-a$, as it is reflected in toponyms like Sân Petru, Sân Giorzan, etc. Another possible explanation for the form Sim-ziana could be the P.I.E. * ${ }^{*}$ sem, som, sm expressing the concept of 'oneness in conjunction with others', a very productive root in I.E. languages. Some examples include Lat. semper, singulus, simplex, simul, Toch. sam-, 'equal, the same', Skt. samtarâm 'together', sambhárana- 'bring together', sam-, 'complete, perfect', samvasa 'living together', Av. hangam, 'to get together', etc., (Caruba 2000). If we apply this root to our Romanian fairy Sim-ziana it could mean that she is a deity belonging to the group of fairies, Rom. zine 'fairies', the simziene, 'one-together with, but unique' among the other fairies, their mistress.

The form with diphton -zeana, ziana from Sim-zeana, Cosân-zeana seems to be the result of assimilation with Ileana, and zâna>zeana. One may have to take into consideration the tabuistic aspect of these developments, as pronouncing these words was regarded as potentially dangerous.

In the Romanian folklore the fairies, zâne, are beautiful and kind, as opposed to iele 'they', fairies that could turn very aggressive towards mankind. Their number is unknown as there are fairies of flowers, of fields and birds, fairies of springs and lakes, and the most important one, 'the fairy of fairies', 'zâna zânelor,' the most beautiful of all, Ileana Simziana. In the spring time the tradition was for children and unmarried youngsters to start a fire, made only of specific woods and the core of ear corns. Around the fire they will put a jug with water, bread and three chairs, in the belief that the fairies will come to wash, eat, warm up by the fire, and bring good luck to the house. (Olinescu 1944: 418) As fairies of flowers the Romanian zâne are spirits of the earth, helpers of the Great Goddess, Ileana Simziana. 


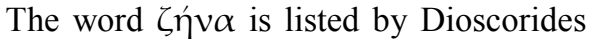
as a Thraco-Dacian word (Russu 1967) with the meaning 'hemlock'. Looking further into this word etymology we find Skt. jyanay-, Av. zyanay-, zyana-, 'to overcome, conquer, weaken', with a reconstructed form * giena $<*$ geie'subjugate, overpower, oppress'. (Detschew 1976) Thus the argument can be made that the Dacian word 'zena' meaning 'hemlock', presents another etymology for the Romanian zîna, plural zîne, feared powerful fairies, that could 'subjugate' 'oppress' people, do damage to their health, cripple them, if not revered. They were companions of Ileana Sim-ziana, the 'simziane, sânziene', are flowers fairies, with their own festival on the summer solstice, the day of collecting medicine herbs, feared and revered by women in many rituals and songs.

One note on the moral aspect of the story, the incest, as in certain areas this was rejected and in others it was accepted. In the Baltic and South Slavic cases the marriage between the two stars was considered normal whereas in the Romanian data is immoral, as in the Indian tradition. These two different attitudes may indicate that the myth was readapted in a newer context when the immorality of incest prevailed, even if it involved two divinities, as the mythical connotations were lost. In the other cases perhaps the emphases was on the astral, non-human, aspect of the characters, thus the incest was not regarded as a moral issue. Both aspects could tell us something about the myth and its development in those regions

\section{References}

Barber 1997: Barber, E. J. W. On the Origin of the vily/rusalki [w:] Varia on the Indo-European Past, The Journal Indo-European Studies - Monograph Series 19 Bolocan 2012. Bolocan, Carmen Maria. Christian Feasts Dedicated to Saints; an Interdisciplinary Perspective; in Annals of 'Stefan cel Mare' Univ., Suceava, Philosophy, Social and Human disciplines series, vol. 1.

Callimachus (1921): Callimachus Hymn III to Artemis, Hymns and Epigrams. Lycophron. Aratus, translated by Mair, W. \& G. R. Loeb Classical Library Volume
129. London: William Heinemann.

Candrea 1927. Candrea, I-Aurel, "Românescul sânziene", Grai și suflet III fasc. 2: 428.

Caruba 2000: Caruba, Onofrio. Indo-European

*sem/sm - in the Pronouns, JIES, Vol. 28, No. 3-4, Fall/Winter.

Chapouthier 1936 : Chapouthier, Ferdinand. Les dioscoures au service d'une déesse; étude

d'iconographie religieuse. Paris.

Detschew 1976: Detschew, D. Die Trakische

Sprachreste, Berlin.

Dundzila 1991: Dundzila, A. V. Maiden, Mother, Crone: Goddesses from Prehistory to European Mythology and Their Reimmergence in German, Lithuanian and Latvian Romantic Dramas. Madison. Eliade 1972: Eliade, M. Zalmoxis, the Vanishing God, Chicago, Univ. of Chicago Press. 1978: A History of Religious Ideas, Chicago, Univ. of Chicago Press. Frazer 1971: Frazer, J. G. Sir. The Golden Bough. New York, Macmillan.

Ghinoiu 1994: Ghinoiu, Ion. Vîrstele timpului, Chişinău, Știința.

2003: Sărbători şi obiceiuri Româneşti, Bucharest, Elion.

Gimbutas 1982: Gimbutas, Marjia. The Goddess and Gods of the Old Europe: Myths and Cult Images.

Univ. of California Press, Los Angeles. 1958: Ancient Symbolism in Lithuanian Fokl Art. Philadelphia, American Folk Society.1968:The Balts, New York, Frederick A. Praeger.

Jones 1995: Jones, Prudence and Pennick, Nigel. $A$ History of Pagan Europe, Routledge, London, New York,

Mallory 1989: Mallory, J. In Seach of the IndoEuropeans. London, Thames \& Hudson.

Mallory \& Adam 1997: Mallory, J. P. \& Adam, D Q.

Encyclopedia of Indo-European Culture. eds. London, Chicago, Fitzroy Dearborn.

2006: Mallory, J. P. \& Adam, D Q. The Oxford Introduction to Proto-Indo-European and the ProtoIndo-European World. New York: Oxford University Press.

Morford 1985: Morford, and Lenardon 1985:

Morford, M.P. and Lenardon Classical Mythology,

New York, Oxford Univ. Press.

Müller 1872: Müller, Max. Chips From a German

Workshop, N.Y, Scribner, vol.2.

Olinescu 1944: Olinescu, Marcel: Mitologie

Românească, Bucuresti, Casa Şcoalelor.

Puhvel 1987: Puhvel, Jaan. Comparative Mythology,

Baltimore, Johns Hopkins University Press.

Russu 1967: Russu, I. I. Limba traco-dacilor,

Bucuresti, Editura Stiințifică.

Sappho, Fragment 199 (Scholiast on Apollonius of Rhodes) (Campbell, Vol. Greek Lyric IV) Greek lyric C5th B.C.

Snorri 2005: Snorri, Sturluson. The Prose of Edda, North Mythology; translated by Jesse Byock. Penguin, 2005.

Vrabie 1966: Vrabie, Gheorghe. Balada populară română, București, Editura Academiei.

Winn 1981: Winn, Shan M. Pre-writing in S-E Europe: the Sign System of Vinca Culture, 4000 B.C. Calgary, Alberta Western Publish 